FKIP Universitas Kuningan

\title{
NAMA JULUKAN ORANG DI DERMO MULYOAGUNG KECAMATAN DAU KABUPATEN MALANG (KAJIAN SEMANTIK)
}

\author{
Suci Puspita Sari \\ Magister Pendidikan Bahasa Indonesia, Universitas Muhammadiyah Malang \\ Sucipuspita3097@gmail.com
}

\begin{abstract}
ABSTRAK: Kajian semantik adalah kajian yang berperan menyelidiki makna dan arti dalam suatu bahasa pada umumnya. Penamaan adalah proses pelabelan terhadap suatu benda, orang, atau peristiwa. Penelitian ini bertujuan untuk (1) mendeskripsikan bentuk-bentuk nama julukan orang dan (2) mendeskripsikan faktor-faktor yang melatarbelakangi nama julukan orang di Dermo Mulyoagung, Kecamatan Dau, Kabupaten Malang. Jenis penelitian ini merupakan jenis kualitatif. Data penelitian berupa aspek semantik meliputi bentuk, makna leksikal, serta faktor yang melatarbelakangi pembentukan nama julukan orang di Dermo Mulyoagung, Kecamatan Dau, Kabupaten Malang. Sumber data dalam penelitian ini adalah informan di Dermo Mulyoagung, Kecamatan Dau, Kabupaten Malang. Teknik pengumpulan data dalam penelitian ini yaitu simak dan catat. Teknik analisis data yang digunakan dalam penelitian ini adalah analisis deskriptif. Hasil penelitian menujukkan bahwa (1) bentuk-bentuk nama julukan orang didasarkan pada jumlah kata, kelas kata, serta sumber bahasa dan (2) faktor yang melatarbelakangi nama julukan orang di Dermo Mulyoagung, Kecamatan Dau, Kabupaten Malang terdiri atas pemendekan, peniruan bunyi, dan sifat khas.
\end{abstract}

Kata Kunci: Nama julukan; penamaan; semantik

\section{NICKNAMES OF PEOPLE IN DERMO MULYOAGUNG DAU DISTRICT MALANG REGENCY (STUDY OF SEMANTIC)}

\begin{abstract}
Semantic is a study that has the role of investigating the meaning and meaning in a language in general. Naming is the process of labeling an object, person or event. This study aims to (1) describe the forms of people's nicknames and (2) describe the factors behind people's nicknames in Dermo Mulyoagung, Dau District, Malang Regency. This type of research is a qualitative type. The research data is in the form of semantic aspects including form, lexical meaning, and the factors behind the formation of people's nicknames in Dermo Mulyoagung, Dau District, Malang Regency. Sources of data in this study were informants at Dermo Mulyoagung, Dau District, Malang Regency. Data collection techniques in this study were listening and taking notes. The data analysis technique used in this research is descriptive analysis. The results of the study show that (1) the forms of people's nicknames are based on the number of words, word classes, and language sources and (2) factors behind people's nicknames in Dermo Mulyoagung, Dau District, Malang Regency consisting of shortening, sound imitation, and distinctive characteristics.

Keywords: Naming; nicknames; semantics

\begin{tabular}{cccc}
\hline Diterima: & Direvisi: & Disetujui: & Dipublikasi: \\
2020-12-18 & 2021-01-27 & $2021-01-30$ & $2021-03-28$ \\
& & \\
Pustaka & sari, s. (2021). KAJIAN SEMANTIK NAMA JULUKAN ORANG DI DESA \\
MULYOAGUNG KECAMATAN DAU KABUPATEN MALANG. Fon : Jurnal Pendidikan & Bahasa dan Sastra Indonesia, 17(1), 65-72. doi:https://doi.org/10.25134/fjpbsi.v17i1.3823 \\
\hline
\end{tabular}
\end{abstract}

\section{PENDAHULUAN}

Kalimat atau tuturan yang dihasilkan oleh manusia baik secara lisan maupun tulisan pasti mengandung makna atau arti. Makna adalah hubungan antara bahasa dengan dunia luar atau fakta-fakta di sekitar manusia yang telah disepakati bersama. Dalam kajian linguistik, terdapat suatu ilmu yang membahas tentang makna dalam suatu bahasa. Cabang linguistik tersebut dikenal sebagai kajian semantik. kajian semantik merupakan suatu sistem yang berperan dalam penyelidikan makna dan arti dalam suatu bahasa atau bahasa pada umumnya (Permata dkk., 2020). Objek pada kajian semantik biasanya 
berupa satuan bahasa yang menyatakan makna atau makna sebenarnya yang tersusun dari satu lingual tanpa tambahan konteks. Selain pada kalimat atau tuturan, adanya suatu makna dapat ditemui pada nama-nama yang disandang oleh manusia atau yang melekat pada seseorang.

Nama adalah sebuah panggilan yang berfungsi sebagai tanda agar dapat membedakan antara makhluk hidup yang satu dengan makhluk hidup lainnya. Dalam kehidupan bermasyarakat sering ditemui adanya nama asli dan nama julukan. Nama asli adalah nama yang sifatnya murni pemberian dari keluarga, sedangkan nama julukan merupakan bentuk sapaan terhadap seseorang yang dapat hadir karena adanya faktor tertentu yang menjadi ciri khas dari individu. Pemberian nama julukan terhadap orang biasanya dilatarbelakangi oleh suasana, peristiwa, maupun unsur lainnya seperti sifat khas karakter, segi fisik, pemendekan atau kebalikan nama, keserupaan, dan penamaan baru. Adanya nama julukan tersebut, termasuk ke dalam salah satu jenis penamaan yaitu penyebutan sifat khas (Muksin, 2015).

Penamaan merupakan proses pelambangan suatu konsep, benda, dan peristiwa untuk mengacu pada suatu referen yang berada di luar bahasa (Chaer, 2013). Nama julukan orang yang ada di Dermo Mulyoagung, Kecamatan Dau, Kabupaten Malang merupakan kata-kata yang disebabkan karena adanya proses penamaan atau pelabelan terhadap seseorang. Pilihan kata yang digunakan dalam nama julukan atau nama panggilan berbeda dengan nama asli. Nama julukan biasanya memiliki pilihan kata yang singkat dan tidak jarang mengandung unsur candaan. Selain itu, pilihan kata yang bervariasi dalam nama julukan juga mengandung makna yang berbeda-beda. Pada umumnya, nama julukan tersebut dipakai sebagai bukti keakraban yang terjalin dalam kehidupan sosial. Bahkan, hingga saat ini masih digunakan untuk menyapa seseorang yang memiliki nama julukan di Dermo Mulyoagung, Kecamatan Dau, Kabupaten Malang.

Dermo merupakan salah satu dusun di Desa Mulyoagung, Kecamatan Dau, Kabupaten Malang. Desa Mulyoagung terdiri atas lima dusun yaitu Jetis, Sengkaling, Dermo, Jetak, dan Jetak Ngasri. Desa Mulyoagung berbatasan dengan desa-desa lain yaitu di sebelah utara sungai brantas dan Desa Tegal Gondo, sebelah selatan Desa Landungsari dan sungai metro, sebelah barat Desa Sumbersekar dan Kota Batu, dan sebelah timur Kota Malang dan Desa Landungsari. Mata pencaharian penduduk di Dusun Dermo yaitu pedagang, buruh, wiraswasta, PNS, dan pensiunan dengan tingkat pendidikan yang sangat beragam.

Dusun Dermo Mulyoagung merupakan dusun tujuan perpindahan penduduk dari kota maupun luar daerah atau provinsi. Hal ini menyebabkan keberadaan penduduk menjadi bersifat heterogen, sehingga berpengaruh pada tata cara kehidupan yang semula bersifat pedesaan menjadi perkotaan. Akan tetapi, hal tersebut tidak menghilangkan rasa saling menghargai dan saling menghormati antarsesama. Masyarakat di Dusun Dermo dapat hidup secara berdampingan dengan menanamkan nilainilai kesopanan dan keramahan yang masih sangat terjaga. Seperti saat berkomunikasi atau bertegur sapa selalu diiringi dengan senyuman dan tundukan kepala dari orang yang lebih muda kepada yang lebih tua. Dalam menyapa seseorang, masyarakat di Dusun Dermo tidak hanya menggunakan nama asli, melainkan juga menggunakaan panggilan tertentu kepada seseorang yang mempunyai julukan atau nama khusus.

Julukan-julukan tersebut ditujukan berdasarkan ciri-ciri atau kekhasan yang melekat pada seseorang di Dusun Dermo. Perbedaan itu dianggap sebagai keunikan 
yang menjadi latarbelakang pembentukan nama julukan orang-orang di dusun itu. Setiap julukan yang dijadikan panggilan khusus, selalu berkaitan dengan hal-hal yang mendasarinya. Seperti sifat, kebiasaan, hingga kondisi fisik yang melekat pada individu-individu tersebut. Salah satu contoh nama julukan yang disandang oleh seseorang di Dusun Dermo Mulyoagung misalnya julukan Gogon yang ditujukan kepada seorang laki-laki yang memiliki nama asli Hadiyono. Hadiyono lebih dikenal dengan sebutan Gogon karena berkaitan dengan kebiasaannya saat masih kecil yaitu suka mencari ikan sambil menyelam yang sering disebut dengan menggogon menurut bahasa Jawa.

Penelitian semantik sejenis yang pernah dilakukan sebelumnya, yaitu sebagai berikut. Pertama, berjudul Semantik Nama Julukan Orang di Desa Sidomulyo Kecamatan Patanahan Kabupaten Kebumen oleh Muksin pada tahun 2015 yang mengkaji tentang faktorfaktor yang melatarbelakangi nama julukan orang di daerah tersebut. Hasil penelitian menunjukkan bahwa faktor yang melatarbelakangi nama julukan yaitu penyebutan bagian, sifat khas, keserupaan, pemendekan, serta makna leksikal terbentuknya nama julukan orang di Desa Sidomulyo Kecamatan Patanahan Kabupaten Kebumen. Persamaan dengan penelitian pertama yaitu meneliti nama julukan orang di daerah tertentu dan faktor yang melatarbelakangi nama julukan orang. Sedangkan, perbedaannya terletak pada permasalahan yang diteliti yaitu bentuk-bentuk nama julukan orang dan tempat penelitian berlangsung. Dalam penelitian yang akan dilakukan lebih berfokus pada nama julukan orang berdasarkan jumlah kata, kelas kata, dan sumber kata.

Kedua, berjudul Penggunaan Bentuk Sapaan Julukan oleh Masyarakat Desa Rumoong-Langsot oleh Lumoindong pada tahun 2017 yang bertujuan untuk mendeskripsikan bentuk-bentuk nama julukan berdasarkan aspek internal dan eksternal dalam linguistik. Hasil penelitian menunjukkan bahwa bentukbentuk nama julukan berdasarkan aspek internal dapat berupa nomina, verba, adjektiva, adverbial, pronomina, frasa nomina, frasa verba, frasa adjektiva, frasa adverbial, ellipsis, dan konjungsi. Sedangkan pada aspek eksternal terdiri atas gelar, istilah kekerabatan, singkatan dan akronim, istilah tabu, pelesetan nama diri, nama istri atau suami, nama orang tua atau mertua, kesalahan pelafalan, dan abnormalitas fisik atau psikis. Oleh sebab itu, persamaan dengan penelitian kedua terletak pada objek kajian yaitu meneliti nama julukan orang di suatu daerah. Selain itu, perbedaannya terdapat pada permasalahan yang dikaji yaitu bentukbentuk nama julukan berdasarkan aspek linguistik, sedangkan pada penelitian ini berfokus pada nama julukan orang yang diklasifikasikan berdasarkan jumlah kata, kelas kata, dan sumber kata.

Berdasarkan uraian di atas maka penelitian ini layak dikaji sebagai pelengkap pada penelitian-penelitian sebelumnya agar lebih relevan dengan teori semantik dalam kajian linguistik. Hal ini disebabkan karena penelitian ini membahas tentang penamaan julukan orang yang mengandung makna leksikal dalam bahasa serta membahas faktorfaktor penyebab terbentuknya nama julukan tersebut. Oleh karena itu, penelitian ini bertujuan untuk mengkaji bentuk-bentuk dan faktor yang melatarbelakangi nama julukan orang di Dermo Mulyoagung Kecamatan Dau Kabupaten Malang

\section{METODE}

Penelitian ini menggunakan metode deskriptif kualitatif karena berfokus pada 
data berupa kalimat atau kata-kata yang berkaitan dengan objek yang diteliti. Penelitian kualitatif adalah suatu mekanisme kerja penelitian yang menggunakan data non angka berupa uraian deskriptif kata atau kalimat yang disusun secara cermat dan sistematis (Ibrahim, 2015). Jenis penelitian tersebut menekankan pada aspek pemahaman secara lebih mendalam terhadap suatu permasalah yang diteliti. Data dalam penelitian ini adalah aspek semantik berupa bentuk dan faktor yang melatarbelakangi pembentukan nama julukan orang di Dermo Mulyoagung, Kecamatan Dau, Kabupaten Malang. Sumber data dalam penelitian ini adalah informan atau orang di Dusun Dermo Desa Mulyoagung, Kecamatan Dau, Kabupaten Malang.

Teknik pengumpulan data adalah cara yang dilakukan untuk memperoleh data penelitian, karena jika data tidak dikumpulkan maka penelitian dipandang tidak berhasil atau gagal. Teknik pengumpulan data yang digunakan dalam penelitian ini, yaitu teknik simak catat. Teknik simak merupakan teknik yang digunakan dalam penelitian bahasa dengan cara menyimak penggunaan bahasa pada objek yang akan diteliti (Sudaryanto, 2015). Teknik simak dilakukan untuk memperoleh informasi secara lengkap dari narasumber atau informan. Kemudian dilanjutkan dengan teknik catat diawali dengan menyiapkan pertanyaan-pertanyaan dan mencatat informasi yang dibutuhkan.

Tahap analisis dilakukan setelah data dalam penelitian terkumpul. Teknik analisis data merupakan upaya yang dilakukan untuk mengelompokkan data dan menangani secara langsung masalah yang terkandung dalam data (Mahsun, 2011). Teknik analisis data yang digunakan dalam penelitian ini adalah teknik analisis deskriptif. Teknik analisis deskriptif dilakukan untuk menguraikan masalah melalui tiga cara yaitu mengklasifikasikan, menyamakan data yang sama, dan membedakan data yang memang berbeda sesuai dengan objek kajian yaitu nama julukan orang di Dermo Mulyoagung, Kecamatan Dau, Kabupaten Malang.

Penyajian data yang digunakan dalam penelitian ini berupa penyajian informal. Penyajian data secara informal adalah penyajian hasil analisis data dengan menggunakan kata-kata yang biasa. Selain itu, dalam menyajikan data juga dilakukan proses seleksi, pengkodean, dan pengkategorian data berdasarkan permasalahan yang diteliti. Oleh karena itu, penyajian data penelitian ini berfokus pada bentuk-bentuk dan faktor-faktor yang melatarbelakangi terbentuknya nama julukan orang di Dermo Mulyoagung, Kecamatan Dau, Kabupaten Malang yang disampaikan menggunakan bahasa sederhana sehingga mudah dipahami.

\section{HASIL DAN PEMBAHASAN}

Dalam kehidupan di lingkungan masyarakat tidak dapat terlepas dari penamaan yang digunakan sebagai identitas masing-masing individu. Pelabelan atau penamaan pada seseorang dianggap penting untuk menghindari kesalahan atau kekeliruan. Pada kenyataanya pemberian nama terhadap seseorang tidak hanya berdasarkan nama asli yang murni pemberian kedua orangtua, tetapi juga terdapat nama julukan yang diberikan kepada orangorang terdekat yang dibentuk karena berbagai faktor, baik ciri fisik, sifat khas, maupun faktor lainnya.

Pada penelitian ini ditemukan nama julukan orang di Dusun Dermo Desa Mulyoagung, Kecamatan Dau, Kabupaten Malang yang berjumlah 31 data. Data-data nama julukan tersebut sebagai berikut: (1) Ambon, (2) Gogon, (3) Hadum, (4) Kiyip, (5) Kilay, (6) Nobek, (7) Makyas, (8) 
Ciprut, (9) Cipluk, (10) Mancung, (11) Tomam, (12) Kecenk, (13) Desainer Jomblo, (14) Onta, (15) Lontong, (16) Hess, (17) Cacing, (18) Kriwil, (19) Rambut Merah, (20) Kalong, (21) Gacul, (22) KD, (23) Molori, (24) Icus, (25) Ginuk, (26) Cebret, (27) Gombong, (28) Gondhes, (29) Plengeh, (30) Gembeng, dan (31) Iik. Berdasarkan data-data di atas, maka penelitian tentang bentukbentuk dan faktor-faktor yang melatarbelakangi nama julukan orang di Dusun Dermo Desa Mulyoagung Kecamatan Dau Kabupaten Malang dapat dipaparkan secara rinci sebagai berikut.

\section{Bentuk-bentuk Nama Julukan Orang di Dermo Mulyoagung, Kecamatan Dau, Kabupaten Malang}

Bentuk-bentuk nama julukan orang di Dermo Mulyoagung, Kecamatan Dau, Kabupaten Malang dapat diklasifikasikan berdasarkan jumlah kata, kelas kata, dan sumber bahasa. Bentuk-bentuk nama julukan tersebut adalah sebagai berikut.

\section{Jumlah Kata}

Jumlah kata pada nama julukan orang di Dermo Mulyoagung, Kecamatan Dau, Kabupaten Malang terdiri atas satu kata dan dua kata. Hal ini dapat dipaparkan pada data-data berikut.

\section{satu kata}

Data (1) julukan Gembeng

Data (2) julukan Cebret

Data (1) dan (2) merupakan penamaan julukan orang yang terbentuk dari satu kata. Data (1) julukan Gembeng terdiri dari satu kata yang memiliki makna mudah menangis. Nama julukan tersebut dapat muncul karena orang yang yang dimaksud memiliki kebiasaan mudah menangis. Selain itu, julukan Gembeng sering dikenal dengan sebutan cengeng yang biasanya sangat identik dengan anak perempuan. Pada data (2) julukan Cebret terdiri dari satu kata yang mempunyai makna mulut. Kata cebret merupakan penamaan julukan orang yang berasal dari sebutan ngecebret dan dalam bahasa Indonesia disebut orang yang banyak bicara atau cerewet.

\section{dua kata}

Data (3) julukan Desainer Jomblo

Data (4) julukan Rambut Merah

Data (3) dan (4) merupakan penamaan julukan orang yang terbentuk dari dua kata. Data (3) julukan Desainer Jomblo bermakna perancang busana yang tidak memiliki pasangan atau pujaan hati. Dalam kehidupan sehari-hari, orang yang tidak memiliki pujaan hati sering dikenal dengan sebutan jomblo. Pada data (4) julukan rambut merah yang terdiri atas dua kata dan bermakna susah diatur. Julukan Rambut Merah identik dengan orang yang berperilaku nakal, galak, suka berkelahi, dan susah diatur.

\section{Kelas Kata}

Bentuk nama julukan orang di Dermo Mulyoagung, Kecamatan Dau, Kabupaten Malang juga dapat dikategorikan berdasarkan kelas kata. Kelas kata dapat dikelompokkan atas kata benda, kata kerja, kata sifat, kata ganti, kata bilangan, kata keterangan, dan kata sambung (Widia, 2016). Dalam penelitian ini, pada nama julukan orang ditemukan dua kelas kata sebagai berikut.

\section{kata sifat}

Data (5) julukan Kriwil

Data (6) julukan Kecenk

Data (5) dan (6) merupakan penamaan yang dibentuk berdasarkan kata sifat. Kata sifat atau adjektiva adalah kata yang digunakan untuk menyatakan sifat atau keadaan suatu hal, baik makhluk hidup, benda mati, tempat, waktu, atau lainnya (Alwi, 2010). Kedua data yang tertera di atas merupakan penamaan yang dibentuk berdasarkan kata sifat yang menunjukkan keadaan fisik pada seseorang. Data (5) adalah data berdasarkan kata sifat yang terlihat pada nama julukan Kriwil. Kriwil merupakan 
kata sifat yang menunjukkan kondisi fisik seseorang yaitu memiliki rambut keriting atau bergelombang. Data (6) terdapat kata sifat yang ditunjukkan pada nama julukan Kecenk. Kecenk adalah kata sifat yang menunjukkan kondisi fisik seseorang karena memiliki tubuh yang kurus dan tinggi.

\section{kata benda}

Data (7) julukan Ambon

Data (8) julukan Onta

Data (7) dan (8) adalah penamaan atau pelabelan pada nama julukan seseorang berdasarkan kata benda. Kata benda atau nomina adalah suatu kata yang merujuk kepada segala hal yang dapat dibendakan baik yang dikenali maupun tidak dapat dikenali indera manusia. Hal ini terlihat pada data (7) merupakan penamaan yang dibentuk berdasarkan kata benda yaitu pada julukan Ambon. Ambon merupakan nama julukan orang yang mengacu pada sebuah kota, yaitu kota Ambon yang termasuk ke dalam contoh kata benda. Pada data (8) merupakan penamaan julukan seseorang yang dibentuk berdasarkan kata benda yaitu Onta. Onta adalah nama julukan yang mengacu pada seekor hewan yang memiliki punuk dan hidup di padang pasir yaitu unta. Julukan tersebut juga termasuk ke dalam contoh kata benda.

\section{Sumber Bahasa}

Nama julukan orang di Dermo Mulyoagung, Kecamatan Dau, Kabupaten Malang dapat dibentuk berdasarkan sumber atau asal mula bahasanya. Sumber bahasa pada nama julukan orang tersebut bersumber dari bahasa Indonesia dan bahasa Jawa yang dipaparkan sebagai berikut.

\section{Bahasa Indonesia}

Data (9) julukan Cacing

Data (10) julukan Lontong

Data (9) dan (10) merupakan penamaan julukan orang yang bersumber dari bahasa Indonesia. Pada data (9) julukan Cacing merupakan nama julukan orang yang memiliki makna berbadan kurus seperti hewan bernama cacing. Dalam bahasa Indonesia, cacing adalah hewan melata yang memiliki tubuh pipih dan panjang. Data (10) julukan Lontong merupakan nama julukan orang yang memiliki makna lembek atau lunak yang diibaratkan seperti lontong yaitu makanan berbahan baku beras dan bertekstur lunak yang dibungkus menggunakan daun pisang.

\section{Bahasa Jawa}

Data (10) julukan Ciprut

Data (11) julukan Cipluk

Data (10) dan (11) adalah penamaan julukan orang yang bersumber dari kata serapan yaitu bahasa Jawa. Data (10) julukan Ciprut adalah nama julukan orang yang memiliki bibir tipis atau dalam bahasa Jawa disebut menciprut. Nama julukan yang bersumber dari bahasa Jawa juga tampak pada data (11) yaitu julukan Cipluk. Julukan tersebut adalah nama yang secara khusus melekat pada seseorang karena memiliki pipi tembem dan bulat atau dalam bahasa Jawa disebut ngecipluk.

\section{Faktor yang Melatarbelakangi Nama Julukan Orang di Dermo Mulyoagung Kecamatan Dau Kabupaten Malang \\ Terbentuknya suatu penamaan} dipengaruhi oleh sebab-sebab yang dapat dilatarbelakangi oleh berbagai faktor seperti peniruan bunyi, penyebutan bagian, penyebutan sifat khas, penemu dan pembuat, tempat asal, bahan, keserupaan, pemendekan, dan penamaan baru (Chaer, 2013). Pada nama julukan orang di Dermo Mulyoagung, Kecamatan Dau, Kabupaten Malang ditemukan tiga faktor yang melatarbelakangi nama julukan tersebut. Faktor-faktor tersebut adalah sebagai berikut.

\section{Pemendekan}

Data (12) julukan $\boldsymbol{K D}$ 


\section{Data (13) julukan Nobek}

Data (12) dan (13) merupakan nama julukan orang berdasarkan pemendekan kata. Pemendekan kata pada nama julukan orang merupakan penamaan yang dilatarbelakangi oleh hasil pemendekan kata atau nama dari orang tersebut (Adam \& Wabang, 2020). Pemendekan dapat berupa singkatan dan akronim. Seperti data (12) julukan $K D$ merupakan julukan yang diberikan oleh masyarakat kepada remaja yang bernama Khilyah Damayanti yang dilatarbelakangi berdasarkan pemendekan kata berupa singkatan menjadi $K D$. Selain itu, remaja tersebut juga memiliki suara yang merdu seperti diva Indonesia yang bernama Krisdayanti. Data (13) julukan Nobek merupakan nama julukan yang diberikan masyarakat kepada remaja yang bernama Nofalia Pebriani yang dilatarbelakangi oleh penggabungan dua kata yaitu Nofalia dan Bebek. Nofalia merupakan kata pertama dari nama asli dan Bebek dilambangkan sebagai seorang wanita yang cerewet, sehingga nama julukan tersebut menjadi Nobek.

\section{Peniruan bunyi}

Data (14) julukan Hes

Data (15) julukan Ginuk

Data (14) dan (15) merupakan nama julukan orang berdasarkan peniruan bunyi. Peniruan bunyi pada nama julukan orang merupakan penamaan yang dilatarbelakangi oleh hasil suara yang ditimbulkan oleh suatu benda tersebut seperti manusia (Kustina, 2020). Pada data (14) julukan Hes merupakan nama julukan orang yang diberikan oleh masyarakat kepada remaja yang bernama Achmad Bahrul Ulum yang dilatarbelakangi karena sejak kecil menyukai racing atau balap motor dan suka mengemudikan kendaraan dengan kencang yang dalam bahasa Jawa berbunyi wes-wes atau hes-hes. Data (15) julukan Ginuk adalah nama julukan yang diberikan masyarakat kepada remaja yang bernama Riesta Maulidya Muaqibah yang dilatarbelakangi karena bertubuh gemuk dan berjalan terkekeh-kekeh seperti raksasa, sehingga langkahnya berbunyi ginak-ginuk.

\section{Sifat khas}

Data (16) julukan Mancung

Data (17) julukan Lontong

Data (16) dan (17) merupakan nama julukan orang berdasarkan penyebutan sifat khas. Penyebutan sifat khas pada nama julukan orang adalah penamaan yang dilatarbelakangi oleh sifat khas yang melekat atau amat menonjol pada seseorang (Muksin, 2015). Pada data (16) julukan Mancung merupakan nama julukan orang yang diberikan oleh masyarakat kepada remaja bernama Muarif Bima Prasetya yang dilatarbelakangi karena memiliki hidung yang makin keujung makin kecil atau mancung. Selanjutnya data (17) julukan Lontong merupakan nama julukan orang yang diberikan oleh masyarakat kepada remaja bernama Abdi Firmansyah yang dilatarbelakangi karena bertubuh besar dengan badan yang genjur atau lembek seperti tekstur lontong yakni beras yang dibungkus daun pisang.

\section{KESIMPULAN}

Berdasarkan hasil pembahasan pada penelitian di atas dapat disimpulkan bahwa nama julukan diberikan seseorang bertujuan untuk memberikan tanda dan menghindari kekeliruan. Nama julukan orang di Dusun Dermo Desa Mulyoagung, Kecamatan Dau, Kabupaten Malang sangat beragam. Keragaman tersebut dapat dilihat dari bentuk-bentuk, makna leksikal, dan faktor yang melatarbelakangi terbentuknya nama julukan orang yang berjumlah sebanyak 31 data.

Nama julukan orang di Dermo Mulyoagung Kabupaten Malang dibentuk berdasarkan jumlah kata yang berupa nama julukan satu kata dan nama julukan 
dua kata, kelas kata yang berupa kata sifat dan kata benda, serta sumber bahasa yang terdiri dari bahasa Indonesia dan bahasa Jawa. Penyebutan nama julukan orang di Dermo Mulyoagung, Kecamatan Dau, Kabupaten Malang dipengaruhi oleh beberapa faktor yaitu pemendekan, peniruan bunyi, dan sifat khas yang terdapat pada orang tersebut. Pemendekan kata terlihat padan nama julukan $K D$ dan Nobek. Penamaan berdasarkan peniruan bunyi terlihat pada nama julukan Hes dan nama julukan Ginuk. Sedangkan, julukan yang berdasarkan sifat khas dapat terbentuknya karena ciri yang menonjol pada seseorang seperti Si Mancung, Si Kriwil, dan Si Onta. Oleh sebab itu, hasil penelitian ini diharapkan dapat dijadikan sebagai referensi pada penelitian selanjutnya, khususnya dalam bidang semantik bahasa Indonesia. Selain itu, penelitian ini juga bersifat memperkuat dan mendukung konsep teori yang telah ada sebelumnya.

\section{DAFTAR PUSTAKA}

Adam, L. N., \& Wabang, R. J. (2020). Pola Singkatan Kata dan Gender. Jubindo: Jurnal Ilmu Pendidikan Bahasa Dan Sastra Indonesia, 4(3), 111-119.

https://doi.org/10.32938/jbi.v4i3.355

Alwi, H. (2010). Tata Bahasa Baku
Bahasa Indonesia. Balai Bahasa.

Chaer, A. (2013). Pengantar Semantik Bahasa Indonesia. PT. Rineka Cipta.

Ibrahim. (2015). Metodologi Penelitian Kualitatif. Perpustakaan Nasional.

Kustina, R. (2020). Onomatope bahasa. Jurnal Metafora, 8(1), 112-119.

Mahsun. (2011). Metode Penelitian Bahasa: Tahapan Strategi, Metode, Dan Tekniknya. PT Rajagrafindo Persada.

Muksin, A. (2015). Kajian Semantik Nama Julukan Orang di Desa Sidomulyo Kecamatan Petanahan Kabupaten Kebumen. Jurnal Program Studi Pendidikan Bahasa Dan Sastra Jawa_Universitas Muhammadiyah Purworejo, 07(04), 12-19.

Permata, F., Dewi, K., Astuti, P. P., Novita, S., \& Medan, U. N. (2020). Metafora Dalam Lirik Lagu Agnez Mo : ASAS: Jurnal Sastra, 9(2), 7280 .

Sudaryanto. (2015). Metode dan Aneka Teknik Analisis Bahasa: Pengantar Penelitian Wahana Kebudayaan secara Linguistis. Sanata Dharma University Press.

Widia, Y. A. (2016). Pemerolehan Kosakata Anak Tunarungu. Skriptorium, 1(2), 129-142. 